\title{
Mjerila primjene prava na zaborav i problem temporalnosti slobode izražavanja pred španjolskim sudovima
}

\section{Matija Miloš}

\author{
UDK : $\quad 342.9(497.17)$ \\ 35.077.2/.3(497.17) \\ Original scientific paper / izvorni znanstveni rad \\ Received / primljeno: 20.9.2016. \\ Accepted / prihvaćeno: 15.3.2017.
}

Ovaj rad ima svrhu doprinijeti raspravi o potencijalnim opasnostima prava na zaborav za slobodu izražavanja na internetu. S tom su se svrhom koristile mjerodavne odluke nadležnih španjolskih sudova, koji su imali prilike razviti bogatu praksu primjene prava na zaborav u kontekstu pretraživača interneta. Nakon isticanja temeljnih mjerila kojima se pravo na zaborav vodilo, štete i javnosti te njezina interesa, u radu se raspravlja o odnosu tih mjerila i slobode izražavanja. Središnje mjerilo jest javnost i njezin interes za informacijom, koji su se u španjolskoj praksi tumačili pozivanjem na pravo na pristup točnoj informaciji. Iako se njime unosi specifična temporalnost slobode izražavanja u tumačenje prava na zaborav, ono u trenutačnom uređenju ne predstavlja bitnu opasnost slobodi izražavanja. Osim toga, moguću opasnost prava na zaborav općenito neutra-

* Matija Miloš, asistent na Katedri za ustavno pravo Pravnog fakulteta Sveučilišta u Rijeci (Assistant at the Chair of on Constitutional Law at the Faculty of Law, University of Rijeka, Croatia, e-mail: mmilos@pravri.hr) 
lizira njegova opravdana ograničenost na specifične internetske pretrage.

Ključne riječi: pravo na zaborav, sloboda izražavanja misli, internet, razmjernost, javni interes, temporalnost

\section{Uvod}

Sud Europske unije izdao je 2014. prethodno mišljenje u predmetu Google Spain. Tumačeći središnji tada važeći izvor europskog prava o zaštiti osobnih podataka, Direktivu 95/46/EZ, Sud je proširio njegovu primjenjivost na pružatelje usluga pretraživanja interneta, kao što je i sâm Google. U tom je kontekstu Sud utvrdio da postoji tzv. »pravo na zaborav«, obvezujući time pružatelje usluge pretraživanja interneta da iz rezultata pretraživanja interneta uklanjaju poveznice koje upućuju na osobne podatke podnositelja zahtjeva za pravom na zaborav. Tome su izložene poveznice čija je dostupnost protivna pravu zaštite osobnih podataka. Pri tome je pružatelj usluge pretraživanja interneta dužan pravo na zaborav primijeniti samo na ono pretraživanje interneta temeljeno na imenu i prezimenu podnositelja zahtjeva.

Godine 2016. stupila je na snagu Uredba o zaštiti osobnih podataka. Ona, između ostaloga, izrijekom uglavljuje pravo na zaborav kao tzv. pravo na brisanje (right to erasure). Time je uvedeno pravo šireg opsega od onoga utvrđenog u predmetu Google Spain, koje se može primijeniti na svaku obradu osobnog podatka na internetu i izvan njega, a ne samo na dostupnost osobnog podatka putem pretraživača interneta.

Primjena zaštite osobnih podataka na internetu izazvala je nezanemarive prigovore u ustavnopravnim krugovima. Američki su pravnici posebno brzo uputili kritiku toj pravnoj inovaciji s aspekta zaštite slobode izražavanja, smatrajući da se dodjeljivanjem prava na brisanje podataka ugrožava slobodno i lako dostupno kolanje govora putem interneta. (Rosen, 2012, para. 12) U osnovi se prigovaralo da je riječ o osobnom pravu na cenzuru informacija koje osoba smatra nepoćudnima. Njegova je problematičnost bila izražena zbog toga što se primjena tog prava trebala odvijati izvan institucija koje inače uravnotežuju primjenu pojedinih temeljnih prava. Pravo na zaborav trebale su, makar u kontekstu pretraživača interneta, provoditi kompanije koje pretraživanje interneta omogućuju.

Iako su prigovori protiv prava na zaborav u ustavnopravnim krugovima već poznati, nisu česta istraživanja koja ispituju kako se u praksi pravo na 
zaborav razvija. Nakon odluke Suda EU-a u slučaju Google Spain razvila se prilika upravo za takvo istraživanje. Stoga je ovaj rad usmjeren na ispitivanje prakse španjolskog upravnog sudstva, koje je svojim prethodnim pitanjem i iniciralo predmet $\mathrm{u}$ kojem je pravo na zaborav prvo uspostavljeno na razini Unije (Silva de Lapuerta, 2014, str. 9) Osim toga, ono je, poslije te odluke, učestalo primjenjivalo pravo na zaborav uspostavljeno u prethodnom mišljenju Suda.

Istraživanje ima dvije svrhe. Prvo, utvrditi kakva su se mjerila primjenjivala u primjeni prava na zaborav. Drugo, ispitati nose li ona kakvu opasnost na slobodu izražavanja i kako u tom svjetlu treba razmišljati o kvalitetnijoj primjeni prava na brisanje i izvan konteksta pretraživača interneta. $U$ tom je smislu moguće istaknuti pitanja javnog interesa i temporalnosti slobode izražavanja, u konkretizaciji kojih će pravo imati važnu ulogu.

U prvom dijelu rada pruža se pregled mjerila primjenjivanih u pogledu prava na zaborav pred nadležnim španjolskim sudovima. $U$ tom su pogledu identificirana dva ključna viđenja prava na zaborav, negativno i pozitivno, koja kao svoju os imaju različita mjerila. Prvo se oslanja na koncept štete, a drugo ističe javnu korist od neke poveznice. U svakom slučaju, oba viđenja prava na zaborav ovise o određenom konceptu javnosti. Kako pravna konceptualizacija javnosti na internetu nosi sjeme napetosti sa slobodom izražavanja, a to je usko vezano i s problemom temporalnosti govora, druga polovica rada usredotočena je na ta pitanja.

\section{Kriteriji primjene prava na zaborav pred španjolskim upravnim sudovima}

U predmetu Google Spain, Sud Europske unije utvrdio je da pojedinac ima pravo na svojevrsnu personalizaciju rezultata pretraživanja interneta koji se temelje na njegovu imenu i prezimenu. Tako postaje moguće tražiti uklanjanje pojedinih poveznica iz tih rezultata koje vode na stranice na kojima se osobni podaci koriste suprotno zahtjevima prava zaštite osobnih podataka.

Takav zahtjev opravdavaju tri međusobno povezane činjenice. Prvo, danas je služenje internetom nezamislivo bez pretraživača. Oni omogućavaju brz i jednostavan pristup širokom spektru informacija. Drugo, pretraživači se u tom kontekstu koriste da bi se saznali detalji o pojedinoj osobi. Upisivanjem imena i prezimena osobe u pretraživač moguće je izgraditi »manje ili više detaljan profil« pojedinca o kojem je riječ (Solove, 2004, str. 46.). 
Treće, postupak stvaranja tog profila sastoji se od dviju radnji. Prva je indeksiranje sadržaja mrežnih stranica, a druga sastavljanje rezultata pojedinih pretraga iz indeksiranjem stvorene baze podataka. Osobe čiji osobni podaci bivaju zahvaćeni tim postupcima u načelu nemaju kontrolu nad njima. To se svakako kosi s privatnošću i zaštitom osobnih podataka ako se mogućnost samoodređenja smatra njihovom idejom vodiljom.

Temeljni spor u vezi s primjenom ovako definiranog prava jest pitanje kriterija po kojima se ona treba ravnati. Već je iz odluke Suda Europske unije bilo jasno da ovdje nije riječ o jednostavnom vetu na »nepoželjnu informaciju«, iako je Sud, pozivajući se na prava na privatnost i zaštitu osobnih podataka, istaknuo da interes suprotstavljen njima treba samo iznimno biti uspješan (Google Spain, para 97). Prije svega, Sud Europske unije apriorno je potpuno diskvalificirao interes pružatelja usluge pretraživanja interneta (Google Spain, para 56, 81, 97 i 99). Njegovo je nastojanje da svojim korisnicima osigura što potpunije rezultate pretraživanja interneta ocijenjeno čisto profitabilnim i kao takvim nedovoljno snažnim za otpor interesu zaštite osobnog podatka. ${ }^{1}$

Osim toga, što je još zanimljivije, Sud Europske unije snažno je diskvalificirao i interes osoba koje internet pretražuju. »Opće je pravilo« zaključuje Sud, »da i interes korisnika interneta mora ustuknuti pred digitalnim zaboravom« (Google Spain, para 81). Iznimku je moguće utvrditi od slučaja do slučaja, i to ako postoji dostatan »interes korisnika « da pristupi spornom podatku. Taj interes prvenstveno treba ovisiti o ulozi pojedinca u »javnom životu«, a u obzir treba uzeti i osjetljivost informacije kao i njezin utjecaj na privatni život osobe o kojoj je riječ (Google Spain, para 81). O brisanju poveznice u konkretnom slučaju odlučuje u prvom redu pružatelj usluge pretraživanja interneta, na čiju je odluku moguće prigovoriti nacionalnim agencijama za zaštitu osobnih podataka te, u krajnjoj liniji, zbog nje pokrenuti upravni spor.

Iako je Uredba o zaštiti osobnih podataka izrijekom postavila neutralniji pristup pravu na zaborav, odnosno "pravu na brisanje«, ističući da se pri odlučivanju o eventualnom brisanju osobnog podatka treba voditi načelom razmjernosti, ${ }^{2}$ jači naglasak na interesu brisanja podatka oprav-

\footnotetext{
${ }^{1}$ Nacionalni sudovi nemaju uvijek isto mišljenje. Upravni odjel Nacionalnog suda Španjolske u nekim je svojim odlukama navodio da Google ima legitiman interes koji nije svodiv na stjecanje dobiti, ali ne navodi u čemu se on sastoji. (vidi odluku spomenutog Suda u predmetu 276/2013).

${ }^{2}$ Već u preambuli Uredbe stoji »Obrada osobnih podataka trebala bi biti osmišljena tako da bude u službi čovječanstva. Pravo na zaštitu osobnih podataka nije apsolutno pravo;
} 
dan je u kontekstu pretraživača interneta. Prvo, riječ je o brisanju koje je ograničeno samo na pretrage temeljene na imenu i prezimenu osobe, što predstavlja znatno ograničenje u primjeni. Ono ostavlja iste poveznice dostupnima u pretragama koje nisu utemeljene na imenu i prezimenu osobe. Zato je i šteta izazvana potencijalno neutemeljenom odlukom o brisanju manja. Drugo, ime i prezime osobni je podatak koji se rijetko mijenja te je usko isprepleten s identitetom pojedinca. Zato se u pogledu normativnog opravdanja može poći od toga da su rezultati pretraživanja temeljeni na tom podatku od posebnog interesa i trebaju biti pod posebnom kontrolom osobe o čijem se imenu i prezimenu radi.

Ipak, previranja o mjerilima po kojima treba ocjenjivati primjenjivost prava na zaborav vide se u praksi španjolskih sudova. Ona postaju očita kada se usporedi praksa upravnog odjela posebnog španjolskog visokog suda ( $A u$ diencia Nacional) ${ }^{3}$ te Vrhovnog suda Španjolske. U španjolskom je pravu jedino upravni odjel tog visokog suda ovlašten odlučivati u sporovima protiv odluka španjolske agencije za zaštitu osobnih podataka. ${ }^{4}$ Osim toga, Vrhovni je sud unio svoje tumačenje prava na zaborav u odlučivanju o građanskoj parnici pokrenutoj izravno protiv španjolskih novina El Pais. Postupak je pokrenut prije odluke Suda Europske unije u Google Spain. Zato je, za razumijevanje primjene središnjih pravila koje španjolsko pravo nameće primjeni prava na zaborav, ključno razmotriti praksu upravu tih dvaju tijela.

Audiencia Nacional odlučila je četrdeset i osam predmeta nakon odluke Suda Europske unije u predmetu Google Spain. ${ }^{5}$ U pravilu je tužitelj u tim

mora se razmatrati u vezi s njegovom funkcijom u društvu te ga treba ujednačiti s drugim temeljnim pravima u skladu s načelom proporcionalnosti. Ovom se Uredbom poštuju sva temeljna prava i uvažavaju slobode i načela priznata Poveljom koja su sadržana u ugovorima, osobito poštovanje privatnog i obiteljskog života, doma i komuniciranja, zaštita osobnih podataka, sloboda mišljenja, savjesti i vjeroispovijedi, sloboda izražavanja i informiranja, sloboda poduzetništva, pravo na učinkovit pravni lijek i pošteno suđenje te pravo na kulturnu, vjersku i jezičnu raznolikost.« (Preambula Uredbe (EU) 2016/679, t. 2).

3 Puni naziv instancije jest Audiencia Nacional, Sala Contencioso-Administrativo.

4 Vidi mjerodavnu odredbu u t. 4 dodatne odredbe Zakona 29/1998. (Ley de 13 de julio, reguladora de la Jurisdicción Contencioso-administrativa).

5 Upravni odjel Nacionalnog suda odlučio je sljedeće predmete (prema broju zahtjeva $-n^{\circ}$ de Recurso): 518/2012 (26. 6. 2015.), 17/2014 (26. 4. 2012.), 411/2012 (30. 3. 2015.), 18/2014 (20. 6. 2015.), 158/2012 (5. 6. 2015.), 180/2012 (2. 6. 2015.), 208/2012 (5. 6. 2015.), $276 / 2013$ (24. 2. 2015.), $278 / 2013$ (1. 6. 2015.), 338/2013 (14. 4. 2015.), 358/2012 (9. 6. 2015.), 493/2012 (24. 2. 2015.), 498/2011 (9. 6. 2015.), 498/2012 (11. 6. 2015.), 500/2012 (20. 2. 2015.), 23/2013 (28. 3. 2015.), 24/2013 (20. 2. 2015.), 45/2013 (29. 2. 2016.), 205/2013 (29. 2. 2015.), 209/2012 (20. 2. 2015.), 227/2012 (5. 2. 2015.), 277/2013 (2. 2. 2015.), 317/2011 (2. 2. 2015.), 337/2013 (2. 2. 2015.), 427/2013 (29. 2. 2015.), 434/2011 (5. 2. 2015.), 489/2012 (27. 2. 2015.), 565/2010 (29. 2. 2015.), 567/2010 
predmetima bio Google kao najznačajniji pružatelj usluga pretraživanja interneta. U svim je takvim predmetima Google nastojao u sporu pobiti odluke Agencije za zaštitu osobnih podataka kojima je naloženo brisanje poveznica u rezultatima pretraživanja interneta. Samo je u pet slučajeva tužitelj bila fizička osoba koja je neuspješno od Agencije tražila brisanje poveznice. ${ }^{6} \mathrm{U}$ dva takva predmeta tužitelj je uspio u sporu, dok je u druga tri Sud potvrdio odluku Agencije. ${ }^{7}$ U jednom je predmetu tužitelj bila fizička osoba koja je prvo neuspješno od Googlea i Agencije tražila brisanje poveznica, a zatim je njezina tužba bila odbijena u upravnom sporu. ${ }^{8} \mathrm{U}$ predmetima u kojima je Google bio tužitelj u pravilu se potvrđivala odluka Agencije. Iznimka su tri slučaja u kojima se tražilo brisanje podatke sa servisa Blogger, koji Google održava (Odluke AN 493/2012, AN 489/2012 i AN 205/2013). Kako je riječ o blogovima za koje potonji samo pruža prostor, ali ne utječe na sadržaj, zahtjevi su odbijeni u dijelu u kojem su se odnosili na tekstove sadržane na njima. Iz sličnih je razloga Google dobio spor u slučaju u kojem se od njega tražilo da briše podatke izravno s mrežnih stranica dnevnog lista (Odluka AN 567/2011).

Svim je sporovima u središtu upotreba imena i prezimena osobe. Do toga dolazi zbog fokusa prava na zaborav. Ono je u konačnici usmjereno na uređivanje onog pretraživanja interneta koje se temelji na tom osobnom podatku. Svaki se predmet zato rješava utvrđivanjem konteksta u koji je ime i prezime u konkretnom slučaju stavljeno, odnosno je li njihovo isticanje nerazmjerno svrsi, zastarjelo ili na drugi način protivno zaštiti

(22. 3. 2015.), 590/2011 (10. 2. 2015.), 662/2009 (12. 2. 2015.), 105/2010 (5. 2. 2015.), $171 / 2012$ (30. 3. 2015.), 303/2013 (28. 3. 2015.), 335/2013 (5. 2. 2015.), 336/2013 (28. 3. 2015.), 359/2010 (3. 2. 2015.), 360/2012 (28. 3. 2015.), 370/2011 (5. 2. 2015.), 456/2011 (28. 3. 2015.), 567/2011 (24. 5. 2013.), 654/2011 (5. 2. 2015.), 690/2011 (3. 2. 2015.), 727/2010 (22. 3. 2015.), 183/2012 (29. 12. 2014.), 110/2014 (6. 10. 2015.), 364/2013 (20. 3. 2015.) i 126/2014 (2. 10. 2015.). Vrhovni je sud o pravu na zaborav odlučivao u predmetu br. 2772/2013 od 15. listopada 2015. Treba istaknuti da su odluke Upravnog odjela Nacionalnog suda uspješno sporene pred Vrhovnim sudom Španjolske zbog postupovnih razloga. Naime, Agencija za zaštitu osobnih podataka i nadležni upravni sud u svojim su odlukama isticali suodgovornost španjolske podružnice Googlea za obradu osobnih podataka, a trebali su odgovornim proglasiti isključivo američku tvrtku, Google Inc. Vidi, primjerice, odluku $1482 / 2015$ od 2. ožujka 2016. (pobijena odluka u predmetu 24/2013), odluku 1300/2015 od 20. lipnja 2016. (pobijena odluka u predmetu 590/2011) i odluku 3275/2011 od 21. lipnja 2016. (pobijena odluka u predmetu 518/2012). Te odluke Vrhovnog suda nisu ulazile u materijalna pitanja primjene prava na zaborav, što jest tema ovog rada, te se stoga rad njima i ne bavi.

${ }^{6}$ Radi se o predmetima 158/2012, 126/2014, 364/2013, 110/2014.

7 Riječ je o predmetima 126/2014 i 110/2014 i 364/2013.

8 Radi se o predmetu 158/2012. 
osobnog podatka. Moguće je da će upotreba imena i prezimena učiniti poveznicu podložnom brisanju jer nerazmjerno vezuje identitet osobe za druge osobne podatke posebne naravi (primjerice zdravstveno stanje pojedinca) ili, najčešće, zbog toga što ga se stavlja u kontekst određenog događaja. Jedan su primjer toga u španjolskoj praksi digitalizirani novinski članci koji opisuju kaznena djela ili prekršaje u vezi s kojima su pokrenuti postupci odavno zaključeni. (Vidi, primjerice, odluke AN 277/2013 i AN 337/2013). Daljnja dostupnost tih članaka u pretraživanju imena i prezimena počinitelja stoga onemogućuje njihovu rehabilitaciju te se u njezinu interesu nalaže uklanjanje spornih poveznica.

Kako bi utvrdilo je li pojava osobnog podatka nedopuštena u tom kontekstu te kao takva podložna brisanju, nadležno španjolsko upravno sudište uzima u obzir niz faktora. Kao primjer može poslužiti njegova najnovija odluka AN 126/2014. U tom je predmetu tužitelj pobijao odluku Agencije kojom je odbijen njegov zahtjev da se iz pretrage bazirane na njegovom imenu i prezimenu izbriše poveznica na članak lista El Pais. U tom je članku, objavljenom 2002., opisana tužiteljeva osuda za prekršaj. Tužitelj je zahtijevao da se poveznica na spomenuti članak izbriše, a Sud se s njime složio. Pri tome je utvrdio da su relevantni razlozi starost informacije, da internetski namjernik može donijeti pogrešan zaključak o tužitelju te da je izgledno da se time nanosi šteta njegovoj karijeri i osobnom životu. Konačno, relevantna je bilo i nepostojanje »osobnih okolnosti« kod tužitelja koje bi mogle izazvati opravdan interes javnosti (odluka AN 126/2014, str. 10). Opravdana »osobna okolnost« predstavljala bi, primjerice, istaknuta uloga podnositelja zahtjeva u političkom životu zemlje.

Faktori na koje se španjolsko upravno sudište pozvalo pojavljuju se u svim drugim predmetima, iako se ne koriste jednakom dosljednošću. Primjerice, šteta koju se nanosi tužitelju, iako uvijek u nekom obliku prisutna, nema postojanu definiciju. Štoviše, pravo na zaborav u formulaciji Suda Europske unije i ne traži da dostupnost određene poveznice u rezultatima pretraživanja »uzrokuje štetu osobi čiji se podaci obrađuju« (Google Spain, para 96). Usprkos tome, u španjolskoj se sudskoj praksi štetu redovito ističe kao bitan sastojak primjene prava na zaborav. ${ }^{9}$ Jedina je razlika u tome što se u manjem broju predmeta njezin opseg određuje vrlo šrroko.

\footnotetext{
9 Ponegdje Audiencia Nacional unosi štetu ispitujući koliko dostupnost poveznice može »utjecati na osobni život« pojedinca, koristeći se u tom smislu i kategorijom »osjetljivog podatka« (V. odluke u predmetima 17/2014, 18/2014, 180/2012, 276/2013, 493/2012, 23/2013, 171/2012, 303/2013, 336/2013, 360/2012, 370/2011, 456/2011, 567/2011, 727/2010). Nju ne treba poistovjećivati s posebnim kategorijama podataka koje Uredba
} 
U jednom je od slučajeva tužiteljica tako tražila da Audiencia Nacional naloži uklanjanje popisa pozvanih na testiranje održano u sklopu natječaja za radno mjesto. Sud je utvrdio da Google mora izbrisati poveznice na taj dokument u pretrazi baziranoj na imenu i prezimenu tužiteljice, iako ne postoji nikakav razlog zbog kojega bi ta informacija mogla štetiti njezinim interesima (odluka AN 335/2013). U svojoj je drugoj odluci Audiencia Nacional ponovo odlučivala o popisu pozvanih na testiranje za drugo radno mjesto, zaključivši da obrada nije potrebna s obzirom na njezin cilj te da zato treba postupiti prema željama osobe kojoj osobni podatak pripada (AN 208/2012). Stoga je moguće zaključiti da je tu već sama dostupnost poveznice bez pristanka osobe o čijim je osobnim podacima riječ izazvala dostatnu štetu, što je blisko zaključivanju Suda Europske unije u predmetu Google Spain.

Zanimljiva je u ovom kontekstu odluka Vrhovnog suda Španjolske u kojoj je izrijekom istaknuto da mora postojati izrazita šteta da bi poveznica bila uklonjena. Odlučujući o pravnom lijeku u građanskoj parnici koju je tužitelj pokrenuo izravno protiv novina El Pais, Sud je utvrdio da je brisanje dopušteno samo ako se kontinuiranom dostupnošću poveznice u rezultatima pretraživanja zasnovanima na imenu i prezimenu osobu »stigmatizira«, odnosno ako joj se onemogućuje uredno funkcioniranje i život u društvu (odluka VS 2772/2013, t. 8.). Vrhovni sud Španjolske time je uglavio izraženu štetu kao ključan preduvjet za primjenu prava na zaborav, suprotno odluci Suda Europske unije i dijelu prakse španjolskog upravnog sudišta nadležnog za pravo na zaborav.

Nadalje, ideju štete Vrhovni sud vezuje za drugi element primjene prava na zaborav, odnosno problem je li osoba »javna«. Za Sud šteta postaje relevantna ako nije riječ o javnoj osobi (odluka VS $2772 / 2013$, t. 8.). Može se pretpostaviti da u slučaju javne osobe treba prevladati interes javnosti, neovisno o šteti koja dostupnošću informacije biva nanesena pojedincu o čijem se osobnom podatku radi. Osim toga, treba istaknuti da se u slučaju odluke Vrhovnog suda osobni podatak pojavljuje u članku izvorno objavljenom u novinama, dok se u dva slučaja u kojima je Audiencia Nacional usvojila krajnje blagu koncepciju štete ime i prezime osobe pojavljuje na jednostavnom popisu pozvanih na testiranje, koji nema jednaku vrijednost u pogledu informacija koje može pružiti općoj javnosti. Na toj je osnovi moguće opravdati

o zaštiti osobnog podatka predviđa u čl. 9. Ovdje se naime ne radi o nekom posebnom osobnom podatku, već u »osjetljivom« kontekstu u koji se ime i prezime stavlja. Takav se »osjetljivi podatak « javlja ako se, primjerice, ime i prezime pojedinca povezuje s optužbom da je riječ o trgovcu drogom (odluke AN 303/2013 i 456/2011) ili s odlukom o pomilovanju koja više nije aktualna (odluka AN 727/2010). 
razliku između konstruiranja štete u slučaju novinskog teksta u usporedbi s popisom koji samo služi administriranju određenog postupka zapošljavanja, iako se sami španjolski sudovi na takve razlike u konkretnim predmetima ne pozivaju. To ne znači da sudovi ne uzimaju u obzir okolnosti u kojima je objavljeni sadržaj izrađen. Tako, iako redovito nastoji razdvojiti pitanje ustavnosti i zakonitosti objave imena i prezimena na mrežnoj stranici od pitanja njegove raširene dostupnosti u tom kontekstu putem tražilica, Sud je istaknuo da je bitno u kakvom je kontekstu identitet osobe istaknut, radi li se o intervjuu i je li kritika konkretne osobe (odluka 158/2012).

Problem »javnosti« zapravo predstavlja središnje pitanje primjene prava na zaborav u Španjolskoj, zbog čega mu je posvećen odvojeni dio rada. Prije otvaranja te rasprave, ovdje treba istaknuti zbog čega bi »javni interes« ili »javnost« trebalo smatrati toliko važnim u primjeni prava na zaborav. To postaje jasnim kada se iz odluka nadležnih španjolskih tijela izvede dva teorijska shvaćanja prava na zaborav: negativno i pozitivno. Moguće ih je razlikovati prema dominantnim mjerilima u primjeni prava na zaborav. Negativno se vodi štetom koju dostupnost poveznice nanosi, dok pozitivno za njezin opstanak traži doprinos »javnom interesu«.

Negativno shvaćanje prava na zaborav, za sada samo deklarativno dominantno u španjolskoj praksi, polazi od toga da šteta mora postojati kako bi poveznica bila uklonjena. U takvoj će analizi dominirati utvrđenje posljedica dostupnosti informacija za osobu. $U$ teoriji bi ovakvo shvaćanje u načelu trebalo biti pogodnije za zadržavanje poveznice jer bi brisanju bile podložni samo sadržaji koji su štetni. Međutim, učinak ovog teorijskog gledišta u praksi ovisi o konkretnoj definiciji štetnosti, zbog čega ovdje primjena odstupa od teorije. U slučajevima u kojima je jedina šteta koja se traži nepostojanje pristanka osobe na dostupnost određene informacije već samo kršenje autonomije pojedinca dovoljna je šteta. ${ }^{10}$

Takvo viđenje prava na zaborav otvoreno je u biti olakšanom uklanjanju sadržaja. Trenutačno još nema odluka nadležnog upravnog sudišta iz kojih bi bilo moguće utvrditi je li već opisani stroži standard štete iz odluke Vrhovnog suda utjecao na ustaljene kriterije nadležnog upravnog suda. U svakom je slučaju

10 Od podnositelja zahtjeva za pravo na zaborav ipak se traži da objasni kako poveznice utječu na njegov osobni i obiteljski život, što znači da u tom shvaćanju pojedinac barem mora učiniti vjerojatnom kakvu-takvu štetu (odluke AN 358/2012, 565/2010, 359/2010, 690/2011). Ovaj zahtjev čini nevaljanim argument po kojemu se zapravo uopće ne traži šteta, jer u takvoj bi situaciji bilo dostatno samo istaknuti želju za uklanjanjem poveznice te naglasiti da osoba koja to traži nije »javna«. U španjolskom pravosudnom iskustvu nema predmeta koji postavlja takve niske kriterije za primjenu prava na zaborav. 
važno istaknuti da »šteta « dolazi u obzir samo ako osoba nije »javna«, odnosno ako se poveznica ne odnosi na pitanje od »javnog interesa«. Ako je riječ o javno značajnom problemu, pitanje štete postaje praktički nebitnim, što je stav nadležnog španjolskog upravnog suda, ali i Vrhovnog suda.

Suprotno od negativnog shvaćanja, pozitivno poimanje prava na zaborav nalagalo bi da se poveznica u pravilu briše. Za njezin je opstanak potpuno nebitno postoji li šteta, već je jedino važno da nema javnog interesa koji bi opravdao njezino zadržavanje. Primjer je takvog rezoniranja predmet noćnog čuvara koji je htio ishoditi uklanjanje poveznice na poziv na testiranje za radno mjesto. Audiencia Nacional utvrdila je da u izostanku jasnog javnog interesa ne može biti ni potrebe održavanja dostupnosti poveznice (odluka AN 208/2012, isto i u odlukama AN 278/2013, 338/2013, 498/2011, 498/2012 i 24/2013). Ovo je gledište potpuno podudarno s pristupom Suda Europske unije te je samo po sebi daleko otvorenije uklanjanju poveznica iz rezultata pretraga. U praksi je zapravo i kriterij štete španjolskog upravnog sudišta primijenjen u pojedinim predmetima približio pravo na zaborav upravo ovom njegovu poimanju.

U španjolskoj se praksi pokazalo da ni negativno ni pozitivno shvaćanje ne obuhvaćaju u potpunosti ulogu elementa »javnog interesa«. U oba shvaćanja on ostaje izvan svih ostalih mjerila te nastupa kao njihov korektiv. Kod negativnog poimanja on će imati presudan utjecaj, na način da će relativizirati štetu ako je osoba »od javnog interesa《 te učiniti brisanje nemogućim. U slučaju osobe koja je, uvjetno rečeno, »privatna«, nepostojanje javnog interesa proširit će ideju štete do te mjere da će i puka dostupnost poveznice dostajati za njezino brisanje. U pozitivnom poimanju prava na zaborav »javnost $« \mathrm{i} » j a v n i$ interes « pretpostavke su za izbjegavanje brisanja poveznice. Ako ih je nemoguće dokazati, ni osporena obrada osobnog podatka ne može opstati. Stoga se »javni interes« pojavljuje kao svojevrsno temeljno mjerilo primjene prava na zaborav. Važno je zato razumjeti kako su u španjolskom slučaju »javnost « i »javni interes« konkretizirani. Važnosti tog problema pridonosi i problem temporalnosti slobode izražavanja koji je isprepleten s konceptom »javnosti«.

\section{Element javnosti u pravu na zaborav i temporalnost slobode izražavanja na internetu}

Španjolska praksa u pogledu prava na zaborav pokazala je da će ključan element njegove primjene biti ideja »javnosti« ili »javnog interesa«. O njoj 
će ovisiti u kojoj će se mjeri u obzir uzimati faktor štete i postoji li legitiman interes za dostupnošću informacije. U konačnici, postoje i predmeti u kojima Audiencia Nacional nije izrijekom uravnoteživala nikakve interese u primjeni prava na zaborav, već je samo utvrdila da je prošlo »dovoljno vremena « da bi se brisanje moglo provesti. ${ }^{11}$ Čak je i u takvim slučajevima problem »javnog interesa osnova na kojoj Sud procjenjuje ima li mjesta za pravo na zaborav. Nadležno će tijelo u takvim slučajevima ispitivati svrhu dostupnosti osobnog podatka u rezultatima pretraživanja. Ona će, zbog toga što pretraživači interneta služe lakšem nalaženju informacija, uvijek biti pružanje određene informacije javnosti putem pretrage izvršene na temelju imena i prezimena osobe. Konačna procjena tada će ovisiti o tome ima li ta javnost još uvijek legitiman interes za takvim pristupom informaciji. Odluka nadležnog tijela zato će nužno pretpostavljati i određenu koncepciju »javnog « i njegova »interesa«.

Pothvat utvrđivanja javnosti u pogledu prava na zaborav opterećen je dvama izazovima. Prvo, pretraživanje interneta inherentno je individualistički čin. Svaki korisnik za sebe, iz vlastitih motiva, upisuje pojam koji ga zanima. Stoga je »javnost« koja se koristi pretraživačem u svojoj naravi zapravo atomizirana i efemerna. ${ }^{12}$ Usprkos tome, za potrebe predmeta u kojem treba primijeniti pravo na zaborav potrebno je utvrditi »interes javnosti«, što pretpostavlja da mora postojati nešto više od puke želje korisnika da pretraživanjem dođe do kakve pikantne informacije o osobi čije ime i prezime pretražuje. Naime, obično se zadiranje u privatnu sferu osobe dopušta samo u onoj mjeri u kojoj je to nužno da bi se zadovoljio javni interes, koji ne može biti pitanje puke znatiželje. ${ }^{13}$ Nadležni španjolski upravni

11 Riječ je o odluci 209/2012.

12 Javnosti koje postoje izvan interneta i javnosti koje se razvijaju isključivo na internetu u postojećim se radovima o slobodi izražavanja na mreži katkada nedovoljno jasno luče (v. Lat \& Shemtob, 2011, str. 413). Tako nije uvijek jasno smatraju li autori da se pravo na zaborav treba voditi prema javnom interesu koji se prema osobi razvija isključivo zbog njezinog djelovanja u virtualnim svjetovima ili se u obzir mora uzeti javni interes koji se razvija izvan njih i koji se koristi mrežom kao dodatnim resursom svojeg izražavanja i potvrđivanja. Ova je druga mogućnost više usklađena s ciljem prava na zaborav, koje bi trebalo osigurati mogućnost prevladavanja prošlosti u svakodnevnom životu. Prema toj logici, pozornost razvijena na osnovi aktivnosti pojedinca koje se odvijaju isključivo na internetu može biti faktor u primjeni prava na zaborav u mjeri u kojoj se takva javnost pretače u svakodnevicu osobe i izvan interneta. Iako španjolski sudovi nikada nisu izravno raspravljali o ovom pitanju, postojeća praksa pokazuje da se vode prvenstveno javnim interesom koji svoj izvor nalazi u djelovanju osobe izvan interneta.

${ }^{13}$ Vidi, primjerice, odluku Europskog suda za ljudska prava u predmetu Mosley protiv Ujedinjenog Kraljevstva (48009/08), u kojem je Sud utvrdio da se slobodu izražavanja u 
sud u svojoj je odluci istaknuo da je pravo na zaborav primjenjivo upravo onda kada je dostupnost osobnog podatka istodobno i povreda privatnog Života $^{14}$ (odluka AN 518/2012, str. 15).

Prema tome, i sudovi su ovdje morali naći način da utvrde interes koji povezuje korisnike interneta iznad njihove znatiželje, koja, sama po sebi, ne bi mogla zaštititi podatke od brisanja. Morali su, dakle, pronaći element interesa javnosti tamo gdje dominira interes mnogih pojedinaca. $U$ konačnici, da to nije zahtjev obrane od prava na zaborav, ni Sud Europske unije ne bi istaknuo da će »u pravilu« interes korisnika biti nevažan, što pretpostavlja da je za njegovo prevladavanje nad digitalnim zaboravom osobe o čijim se osobnim podacima radi zapravo potrebna neka vrsta ozbiljnog opravdanja.

Drugi je izazov fluidna priroda komuniciranja putem interneta. Dok su tradicionalnija sredstva prenošenja informacija koliko-toliko ograničena na prostor određene političke zajednice, internet preskače te granice, i prostorno i vremenski. To izravno utječe na problem interesa javnosti za pristup informacijama, jer pretežna ograničenost komuniciranja na određenu političku zajednicu za sobom povlači i spektar pitanja koja u okvirima te zajednice mogu biti od javnog interesa. Njihov je opseg nužno širok pa će, uz raspravu o političkoj odgovornosti kakvog ministra, u reflektoru javnosti biti i ljubavni život vrhunskog sportaša. ${ }^{15}$ Dakle, konture javnog interesa u tom su pogledu otvorene te uvelike prepuštene samoregulaciji sudionika javne rasprave, kako medija tako i njihove publike. Ipak, barem minimalne granice uvijek postoje jer se u pravnom tumačenju javnog interesa pretpostavlja postojanje jedne javnosti koja u određenom vremenu ima interes za određenim pitanjima. ${ }^{16} \mathrm{Na}$ internetu pak ne postoji jedna

kontekstu medija treba uže tumačiti ako izvještavanje ne doprinosi nekom pitanju od javnog interesa, već služi samo zabavljanju javnosti i zadovoljenju njezine znatiželje.

14 Takvo je poistovjećivanje dvaju prava dvojbeno zbog toga što je zaštita osobnih podataka šira od privatnosti i intime te obuhvaća svaki podatak koji osobu »identificira ili može identificirati«. Zato bi u njezinoj dosljednoj primjeni i osobni podatak koji ne čini dio nečijeg privatnog ili osobnog života morao biti potencijalnim predmetom prava na zaborav. 2011.

15 V. predmet Rio Ferdinand v. MGN Limited, [2011] EWHC 2454 (QB) od 29. rujna

${ }^{16} \mathrm{U}$ ovom pogledu postoje zanimljive razlike između država. Primjerice, dok je postojanje izvanbračnog djeteta prestolonasljednika Monaka u Njemačkoj bilo shvaćeno kao prvorazredno javno pitanje zbog toga što je Monako ustavna monarhija pa je pitanje nasljeđivanja istaknuto u političkoj sferi, francuski su sudovi došli do dijametralno suprotnog zaključka. Za njih je spomenuto očinstvo u bitnome bilo privatno pitanje kojemu u javnom prostoru nema mjesta (v. odluku Europskog suda za ljudska prava u predmetu Couderc and Hachette Filipacchi Associés protiv Francuske (40454/07)). 
»svjetska javnost« već, ponovo, niz korisnika koji mogu i ne moraju pripadati istoj političkoj zajednici i generaciji kojoj je u određenom vremenu neko pitanje zaista bilo od interesa.

Kako bi doskočili tim izazovima, Audiencia Nacional i Vrhovni sud Španjolske primijenili su isti pristup, oslonivši se na određene kriterije »javnosti« $\mathrm{i} » j a v n o g$ interesa. Tako Vrhovni sud u svojoj, već citiranoj, odluci ističe da će javni interes postojati onda ako je ime i prezime pojedinca upleteno u informaciju koja služi »oblikovanju osnovanog mišljenja o pitanjima od važnosti za funkcioniranje demokratskog društva«, bilo da je riječ o političkoj, ekonomskoj ili kakvoj drugoj sferi (odluka VS 2772/2013, t. 5.6.). Za konkretizaciju javnosti i njezinog interesa Audiencia Nacional oslonila se na dvije kategorije »javne osobe« poznate slobodi izražavanja. Prvo, osobe koja je, zbog svoje izražene uloge u javnom životu, javna u svakom slučaju. Političari redovito pripadaju toj kategoriji. (primjer predstavlja odluka AN 158/2012). Druga je kategorija osoba koje su upletene u neko pitanje od posebnog javnog interesa, kao što je kakvo kazneno djelo, te se u kontekstu tog problema smatraju javnima (primjer je odluka AN 498/2012). Sama rodbinska povezanost s takvom osobom ne čini drugoga javnom ličnošću (odluka AN 110/2014).

Ovakva konkretizacija javnosti i javnog interesa u španjolskom pravu nije inovacija prava na zaborav. Ona predstavlja preuzimanje sadržaja određenog temeljnog prava, prava na primanje točne informacije zaštićenog čl. 20(1)(d) Ustava Španjolske. Iako zaštićeno istim člankom kao i sloboda izražavanja misli uopće, ono štiti samo neke sadržaje i u pogledu njih ima prednost u odnosu prema pravu na privatnost. Kao što ističe Bustos Gisbert, u njegov opseg potpadaju informacije koje se tiču »događaja od javne važnosti« te su kao takve »potrebne za ostvarivanje stvarnog sudjelovanja građana u kolektivnom životu«. To moraju biti informacije koje su bitne svim građanima, a ne samo pojedincima ili nekim dijelovima građanstva (Bustos Gisbert, 1994, str. 277 i 282). U jednoj od svojih novijih odluka, Ustavni sud ističe pravo na primanje točne informacije kao pravo koje se po tom svojem specijaliziranom opsegu razlikuje od slobode izražavanja koja štiti, primjerice, i vrijednosne sudove (odluka TC 16538/2010, str. 22).

Izbor mjerila ukorijenjenih u pravu koje nema širinu istovjetnu slobodi izražavanja ima dvije posljedice. Sadržajno, pravo na primanje istinitih informacija usmjereno je na zaštitu sadržaja koji informiraju javnost, odnosno onih koji su prvenstveno činjenično orijentirani. To znači da bi pravo na zaborav, primijenjeno na pretraživače interneta, trebalo slabije pogađati osobne podatke sadržane u činjeničnim tvrdnjama, dok bi vrijednosni 
sudovi, u mjeri u kojoj ih je moguće razlikovati od činjeničnih tvrdnji, na njega bili ranjiviji. ${ }^{17}$ Primjer je toga predmet u kojem je povezivanje imena i prezimena osobe s grubom uvredom ocijenjeno neprimjerenim te podložnim brisanju (odluka AN 183/2012). Druga posljedica izbora mjerila ukotvljenih u pravo na primanje točne informacije leži u tome što to pretpostavlja postojanje jedinstvene javne sfere u kojoj informacije nastaju i nalaze svoju publiku. Ona se ne iscrpljuje u političkim pitanjima, iako kriterij participacije u »kolektivnom životu« svakako poseban naglasak stavlja upravo na govor koji se njih dotiče.

S druge strane, izražavanje na internetu nije svedivo na jedinstvenu javnu sferu niti na politički govor. Kao što ističe Balkin, njegov primarni cilj nije rasprava koja bi bila vrijedna upravljanju političkom zajednicom, već ponajprije govor koji teži »stvaranju i održavanju kulture« (Balkin, 2004, str. 3). U usporedbi s tim drugim sadržajima internetskog govora, izražavanje koje bi bilo uklopljeno u bilo što političko blijedi svojim opsegom (Dahlgren, 2005, str. 151). Ono što je bitno za pojedine političke zajednice biva utopljeno u nizu svojih alternativa i pravaca od kojih neki s time imaju malo ili nemaju nikakve veze. Demokratizirajući govor na taj način, internet na površinu zapravo iznosi samo činjenicu mnogostrukosti javne sfere u sklopu koje, uz onu zabavljenu političkim, ekonomskim i kulturnim pitanjima koja su fokus pažnje čitave zajednice, postoji i niz podsfera, u kojima osoba može uživati različite stupnjeve prepoznatljivosti između polova javnosti i anonimnosti. ${ }^{18}$

Temeljni je problem potencijalno nedovoljna osjetljivost prava na zaborav na tu činjenicu. Ako je središnji kriterij odmjeravanja javnosti utemeljen na ideji o središnjoj javnoj sferi u prostoru koji takve sfere zapravo nema, postoji mogućnost da će od brisanja biti izuzete samo one poveznice koje

17 Sami po sebi, osobni podaci nisu istovjetni vrijednosnim sudovima. Za potrebe slobode izražavanja čini se ispravnijim smatrati ih bliskima činjenicama. Naime, njihovo korištenje mora udovoljavati zahtjevima koji, između ostaloga, trebaju osiguravati njihovu točnost te njihovo zakonito i razmjerno korištenje (Wong i Savirimuthu, 2008, str. 243). Istodobno, osobni podaci nisu činjenice razvedene od konkretnih osoba, jer oni se uvijek »odnose na pojedinca čiji je identitet utvrđen ili se može utvrditi« (Uredba o zaštiti osobnih podataka, čl. 4(1)(1)). Zato i dolazi do snažnog naglaska na autonomiju osobe na koju se ti podaci odnose, a samim time i na njihove subjektivne sudove. Stoga bi i kod osobnog podatka uklopljenog u vrijednosni sud bilo neispravno tvrditi da on predstavlja vrijednosni sud pojedinca koji izriče svoj stav. Naime, i u takvoj situaciji treba adekvatno zaštititi sud osobe kojoj osobni podaci pripadaju i bez koje u konačnici i ne bi bili osobni.

${ }^{18}$ U tom je pogledu ovaj argument blizak kritici koju je Nancy Fraser uputila Habermasovu monolitnom razumijevanju javne sfere, ali pri tome ne implicira da je internet neka vrsta globalne javne sfere (v. šire Papacharissi, 2008, str. 230-245). 
se mogu uklopiti u nj (Miloš, 2016, str. 457). Prema tome, ako je riječ o sadržajima koji više ne bi bili aktualni za neku političku zajednicu uopće ili o onima koji to nikada ne bi ni bili, oni će biti podložniji pravu na zaborav.

U osnovi je ovdje riječ o pitanju temporalnosti izražavanja. ${ }^{19}$ Naime, pravom na zaborav nastoji se pravno konstruirati »zaborav« u kontekstu tehnologije koja mu se opire. Cilj je ograničiti dostupnost sadržajima koji su, posebno zbog proteka vremena, zastarjeli ili nerazmjerni svrsi (Google Spain, para 93). Da bi se pravom na zaborav utvrdilo je li tome zaista tako u svakom pojedinom slučaju, ono se ne može osloniti na kronološki tok vremena. Drugim riječima, »zastarijevanje« osobnog podatka, a s njime i informacije, ne može ovisiti o fiksnom vremenu (Korenhof et al., 2014, str. 2). Ono se oblikuje prema zahtjevima svake konkretne, društveno uvjetovane situacije. Prema tome, važno je postoje li osnove za utvrđivanje da neka zajednica može smatrati informaciju i dalje relevantnom u vrijeme kada se traži njezino brisanje. Ne mora se nužno raditi o kriterijima neke nacionalne javne sfere, već može biti riječ i o užoj javnosti. Zbog toga bi bilo neispravno svoditi primjenu prava na zaborav na pitanje je li osoba javna ili privatna u smislu nacionalne politike, kulture ili ekonomije. Kriterij štete, kao i razmatranje konteksta u kojem se osobni podatak nalazi, neizostavni su elementi analize.

Određivanje govora od »javnog interesa« nije kontroverzno samo stoga što postoje neslaganja o tome što bi trebalo biti legitimnim i zakonitim predmetom široke javne rasprave, već i zato što je riječ o pitanju koje je prožeto problemom moći i njezine raspodjele. Naime, postavlja se pitanje mjere u kojoj bi sama javnost trebala krojiti sadržaj i granice javne rasprave te trebaju li se i koliko u taj pothvat upletati tijela javne vlasti. Strahovanje od potencijalno negativnog utjecaja države u nekim je slučajevima posebno izraženo. Zaštitu slobode govora u Sjedinjenim Američkim Državama tako karakterizira strah od utjecaja sudstva na javnu raspravu. On je dodatno poduprijet samom kulturom sudaca koji smatraju da nisu pozvani odlučivati o tome što je dopustivo u javnoj raspravi, ali i, prema nekim autorima, moćnom kulturalnom aurom Prvog amandmana koji stoji kao istaknuto tekstualno jamstvo slobode izražavanja, dok je, s druge strane, privatnost u prvom redu plod sudskog djelovanja (Hughes \& Richards, 2015, str. 172).

Pravo na zaborav oživjelo je te aspekte rasprave o slobodi izražavanja u kontekstu interneta. Postupak izbora između različitih temporalnosti go-

19 Općenito o konceptu temporalnosti v. French, 2001. 
vora tako je postao kontroverzan i zbog njegovog načina pokretanja i provođenja. Prije svega, neki su kritičari prozvali pravo na zaborav začetkom prava pojedinca da na internetu provodi cenzuru. Osoba kojoj smeta neki sadržaj obraća se pružatelju usluge pretraživanja interneta koji potiskuje nezgodan kontekst u kojem se nečije ime i prezime pojavljuje (Rosen, 2011, str. 352). Taj je proces potiskivanja sporan ne samo zbog toga što je moguć već zbog toga što ga ne provodi ni sud niti drugo tijelo javne vlasti, već sam pružatelj pretraživanja usluge interneta. Takav bi se pristup mogao označiti nedovoljno otvorenim, posebno zbog toga što pojedinac postupak može pokrenuti i u njemu sudjelovati, a da stranka o čijoj se mrežnoj stranici radi ne sazna za njega.

Bojazni vezane za institucionalne i postupovne aspekte prava na zaborav istodobno su korisne i pretjerane. Korisne su zato što pokazuju potencijalne probleme ako bi se pravo na zaborav počelo primjenjivati na osobne podatke izvan konteksta pretraživača interneta. Posebno stoje prigovori usmjereni na postupak brisanja poveznica. Njihova je snaga, kao što se u nastavku navodi, ipak relativizirana sve dok se pravo na zaborav ograničava samo na pretraživanje interneta, i to samo u pogledu imena i prezimena pojedinca. Osim toga, prigovori su dijelom pretjerani. Naime, pretpostavljaju da su rezultati pretraživanja interneta, lišeni prava na zaborav, neutralni i potpuni. Pri tome zanemaruju da su rezultati pretraživanja po definiciji filtrirani, i to u postupku koji je netransparentan (Leaver, Willson, \& Balnaves, 2012). Zato se rezultati mogu smatrati neutralnima samo ako neutralnost znači primjenu jednom izrađenog koda bez neposrednog upletanja ljudskog faktora.

Težnja prema osiguravanju dostupnosti sadržaja pretraživanjem interneta bez navodne arbitrarnosti pojedinaca isto tako zanemaruje u kojem se kontekstu pravo na zaborav stvarno primjenjuje. Napadajući pravo na zaborav in abstracto, oštrica kritike oduzima na značenju činjenicu da je primjenjivost ograničena na pretraživanje utemeljeno na imenu i prezimenu osobe. Nadalje, ona je, barem u španjolskoj praksi, ograničena isključivo na opće pretraživače interneta. Iz opsega prava na zaborav izuzimaju se tzv. specijalizirani pretraživači, čiji pružatelj može biti i Google. Te tražilice rezultate sastavljaju samo iz sadržaja stranice za potrebe koje su uspostavljene. Vrhovni sud Španjolske utvrdio je da bi se primjenom prava na zaborav na njih ugrozila arhivska funkcija stranice te nerazmjerno otežalo pretraživanje informacija (odluka VS 2772/2013, t. 7.4, v. i odluku AN 364/2013). Prema tome, u praksi se pravo na zaborav za sada potvrdilo kao sredstvo otežavanja prejednostavnog nalaženja nekih informacija o konkretnoj osobi. Iste je informacije, treba ponoviti, moguće naći putem 
drugih pretraga interneta koje će, umjesto na ime i prezime, biti usmjerene na, primjerice, trgovinu drogom ili korupciju.

U svojoj trenutačnoj primjeni na pretraživače interneta pravo na zaborav ima smisla zbog temporalnog djelovanja pretraživača interneta. Oni pojedine dijelove dostupnih mrežnih stranica izlažu, na zahtjev korisnika, na stranici s rezultatima. Tada ti različiti segmenti sadržaja dostupnih na internetu dobivaju nov kontekst. Sami po sebi, dakle, internetski pretraživači ne pridaju važnost nekoj koncepciji društvenog vremena te su u tom smislu atemporalni. Oni vade informacije iz mnoštva različitih konteksta i sastavljaju ih u jedno, temporalno sterilno okruženje. U slučajevima u kojima se pravo na zaborav primjenjuje, zajednička točka tih dekontekstualiziranih digitalnih sadržaja postaje nečije ime i prezime. Ako se osobi u takvoj situaciji ne bi priznala mogućnost utjecanja upravo na te rezultate pretraživanja, to bi značilo da ona u određenoj mjeri postaje predmetom, pukim sredstvom zadovoljenja nečije znatiželje. Takav bi se pristup mogao smatrati povredom dostojanstva osobe o čijem je imenu i prezimenu riječ (Barak, 2015, str. 117).

Suprotno tomu, tvrditi da pravo na zaborav općenito predstavlja znatnu prijetnju slobodi izražavanja čini se pretjeranim. U konačnici, njime se i ne dovodi u pitanje ustavnost i zakonitost izvornog čina izražavanja. Štoviše, u primjeni prava na zaborav, nadležno tijelo ne svodi analizu na retrospektivno preispitivanje okolnosti u trenutku objave sadržaja na mrežnoj stranici (Pazos Castro, 2016, str. 14). Ipak ne treba izgubiti iz vida da izvorni izričaj i njegova dostupnost na pretraživaču nisu potpuno pravno nepovezani. Primjerice, ustavnost, zakonitost i pravodobnost sadržaja na mrežnoj stranici, barem prema španjolskim kriterijima, otežava brisanje predmetne poveznice u pretrazi temeljenoj na imenu i prezimenu osobe (v. odluku AN 110/2014). Međutim, kao što je već istaknuto, čak će i u slučaju brisanja sporni sadržaj biti moguće pronaći po drugim kriterijima budući da se pravo na zaborav još uvijek ne primjenjuje na same mrežne stranice.

S druge pak strane, problematično bi bilo kada bi pravo na zaborav postalo istaknutijim sredstvom rješavanja sukoba između slobode izražavanja i njima suprotstavljenih prava, prvenstveno prava na privatan i obiteljski život. To, naravno, pod uvjetom da se ovdje raspravljeni kriteriji jednostavno prenesu iz konteksta pretraživača interneta i takvi primijene na mrežne stranice. $U$ toj bi situaciji sve istaknute kritke povezane s konceptom javnosti i njezine temporalnosti dobile na značenju. Međutim, iz same trenutačno važeće Uredbe za zaštitu osobnih prava nije moguće predvidjeti taj razvoj, posebno s obzirom na izniman naglasak na razmjernosti i 
potrebi zaštite slobode izražavanja. Niti dosadašnje iskustvo s primjenom prava na zaborav u Španjolskoj ne daje naznačiti da bi ono moglo na taj način postati problematično.

\section{Zaključak}

Svrha je ovog rada bila doprinijeti raspravi o odnosu prava na zaborav i slobode izražavanja na internetu. Tekst koji je prethodio ovom zaključku svoj je doprinos u pogledu tog pitanja usmjerio na praksu nadležnog španjolskog upravnog suda te mjerodavnu odluku Vrhovnog suda Španjolske. Na taj se način, umjesto uopćene ocjene mogućih problema s primjenom prava na zaborav, htjelo istražiti kakva su mjerila sudovi konkretne države osmislili kako bi pomirili suprotstavljena prava. U fokusu je rasprave, nadalje, bilo jesu li ta mjerila problematična za slobodu izražavanja na internetu.

Moguće je zaključiti da pravo na zaborav u Španjolskoj trenutačno ne predstavlja opasnost za slobodu izražavanja na internetu. Istraživanje je pokazalo da pravo na zaborav, kako se u Španjolskoj trenutačno primjenjuje, posebno ovisi o mjerilima štete te javnosti i javnog interesa. U praksi se pak pokazuje da upravo mjerilo javnosti i javnog interesa ima pretežito značenje te da o njemu ovisi hoće li se i koliko druga mjerila, a posebno šteta, uzimati u obzir. Potencijalni je problem s javnošću u tome što se njezin sadržaj određuje oslanjanjem na ustavnopravnu teoriju razvijenu u kontekstu prava na pristup točnim informacijama, što oblikuje i utjecaj prava na zaborav. Osim tog materijalnopravnog problema, institucionalni i postupovni problem prava na zaborav počiva u netransparentnom postupku udaljenom od tijela javne vlasti.

Potencijalne probleme s primjenom prava na zaborav u Španjolskoj ograničava njezino strogo zadržavanje u okvirima pretraživača interneta, $i$ to samo u pogledu onih pretraga koje se odnose na ime i prezime osobe. Vezivanje prava na zaborav uz potonji osobni podatak nalazi svoje snažno opravdanje u time što se automatiziranim i neselektivnim indeksiranjem sadržaja koji uključuju osobne podatke omogućuje lako profiliranje osobe. Ona može postati pukim predmetom pretrage te je stoga utemeljeno dati posebno značenje upravo njezinom položaju te joj omogućiti utjecaj na profil koji pretraga interneta stvara.

Ako bi pravo na zaborav bilo primijenjeno izvan tog konteksta, ne bi bilo poželjno zadržati njegova trenutna obilježja. Ono bi se moralo uklopiti u 
klasičnu analizu razmjernosti koja se redovito primjenjuje i u srazu svih temeljnih prava, a čini se da za budućnost upravo takav scenarij predviđa i Uredba o zaštiti osobnih podataka, koja je stupila na snagu 2016. godine.

Ograničenje je ovog istraživanja prije svega u tome što je usredotočeno na jednu državu. Drugo je ograničenje u izdvajanju isključivo sudske prakse. Iako je ona poslužila utvrđivanju mjerila primjene prava na zaborav koja se razvijaju na najvišoj instanciji zaduženoj za njegovu primjenu, tek predstoji istražiti kako se ona odražavaju u djelovanju nadležne agencije za zaštitu osobnih podataka. Bilo bi zanimljivo ovdje istaknuta mjerila dovesti u vezu i s primjenom prava na zaborav u djelovanju samih pružatelja usluge pretraživanja interneta. Međutim, kako su njihove odluke gotovo potpuno nedostupne javnosti, takvo istraživanje trenutačno nije provedivo.

\section{Literatura}

Balkin, J. M. (2004). Digital Speech and Democratic Culture: A Theory of Freedom of Expression for the Information Society, New York University Law Review, 79(1), 1-55.

Barak, A. (2015). Human Dignity: The Constitutional Value and the Constitutional Right, Cambridge, UK: Cambridge University Press.

Bustos Gisbert, R. (1994). El concepto del libertad de informacion a partir de su distincion de la libertad de expresion, Revista de Estudios Políticos (Nueva Epoca), 54(85), 261-289.

Dahlgren, P. (2005). The Internet, Public Sphere, and Political Communication: Dispersion and Deliberation, Political Communication, 22(2), 147-162.

French, R. R. (2001). Time in the Law, University of Colorado Law Review, 72(3), 663-748.

Hughes, K. \& Richards, N. M. (2015). The Atlantic Divide on Privacy and Free Speech. U A. T. Kenyon (ur.) Comparative Defamation and Privacy Law (str. 164-198). Cambridge, UK: Cambridge University Press

Korenhof, P., Ausloos, J., Szekely, I., Ambrose, M., Sartor, G. \& Leenes, R. (2014). Timing the Right to be Forgotten: A study into "time" as a factor in deciding about retention or erasure of data. Preuzeto sa Social Science Research Network: http://ssrn.com/abstract=2436436 http://dx.doi.org/10.2139/ssrn.2436436.

Lat, D., \& Shemtob, Z. (2011). Public Figurehood in the Digital Age, Journal on Telecommunication and High Technology Law, 9(2), 403-419.

Leaver, T., Willson, M., \& Balnaves, M. (2012). Transparency and the Ubiquity of Information Filtration?, Ctrl-Z: New Media Pbilosophy, 1(2):1-14. Preuzeto s mrežne stranice časopisa http://bit.ly/1CLvcI6.

Miloš, M. (2016). Private and Public Dimensions of Personal Data in Online Speech: Lessons from the Right to be Forgotten. U A. Balthasar, B. Golob, H. Hansen, R. Müller-Török, A. Nemeslaki, J. Pichler \& A. Prosser (ur.) CEE 
eDem and eGov Days 2016: Multi-Level (e)Governance: Is ICT a means to enbance transparency and democracy? (str. 451-462). Beč, Austrija: Oesterreichische Computer Gesellschaft

Papacharissi, Z. (2008). The virtual sphere 2.0. A. Chadwick \& P. N. Howard (ur.) Routledge Handbook of Internet Politics (str. 230-245). Abingdon, UK: Routledge.

Pazos Castro, R. (2016). El derecho al olvido frente a los editores de hemerotecas digitales: A proposito de la STS (Pleno de la Sala 1a) de 15 de octubre de 2015, Revista para el análisis del derecho, 1(4), 1-49.

Rosen, J. (2011). Free Speech, Privacy, and the Web That Never Forgets, Journal on Telecommunication \& High Technology Law, 9(2), 345-356.

Rosen, J. (2012). The Right to be Forgotten. Stanford Law Review Online. Preuzeto s mrežne stranice časopisa: http://stanford.io/2iZ0sjO.

Silva de Lapuerta, M. (2014). El "derecho al olvido" como aportación Espaòola y el papel dela Abogacía del Estado, Actualidad Juridica Uría Menéndez, 7-12. Preuzeto s mrežne stranice časopisa http://bit.ly/2ibXc4W.

Solove, D. (2004). The Digital Person: Technology and Privacy in the Digital Age, New York, SAD: New York University Press.

Wong, R. \& Savirimuthu, J. (2008). All or nothing: this is the question? The application of Article 3(2) Data Protection Directive 95/46/EC to the internet, Jobn Marshall Journal of Computer \& Information Law, 25(2), 241-266.

\section{Propisi}

Ley de 13 de julio, reguladora de la Jurisdicción Contencioso-administrativa, Boletin Oficial del Estado, nr. 167 (14. 7. 1998.).

Uredba (EU) 2016/679 Europskog parlamenta i Vijeća od 27. travnja 2016. o zaštiti pojedinaca u vezi s obradom osobnih podataka i o slobodnom kretanju takvih podataka te o stavljanju izvan snage Direktive 95/46/EZ, OJ L 119, 4.5.2016, str. 1-88.

\section{Sudske odluke}

Odluka Suda Europske unije (veliko vijeće) Google Inc. vs. Agencia de Protección de Datos (AEPD), Mario Costeja Gonzales, EU:C:2014:317, predmet C-131/12, 13.5.2014. (Google Spain)

Couderc and Hachette Filipacchi Associés vs. Francuske, zahtjev br. 40454/07, 12. 6. 2014.

Mosley vs. Ujedinjenog Kraljevstva, zahtjev br. 48009/08, 10. 5. 2011.

Rio Ferdinand vs. MGN Limited, [2011] EWHC 2454 (QB), 29. 9. 2011.

Odluka Građanskog odjela Vrhovnog suda Španjolske, 2772/2013, TS:2015:4132, 15. 10. 2015 
Odluke Upravnog odjela Vrhovnog suda Španjolske (navedene prema broju predmeta, ECLI oznaci i datumu)

3275/2011, ES:TS:2016:3706., 21. 6. 2016.

1300/2015, ES:TS:2016:2842., 20. 6. 2016.

1482/2015, ES:TS:2016:1055, 2. 3. 2016.

Odluke Upravnog odjela Visokog suda Španjolske (Audiencia Nacional) (navedene prema broju zahtjeva ( $n^{\circ}$ de Recurso), ECLI oznaci i datumu)

45/2013, ES:AN:2015:623., 29. 2. 2016.

662/2009, ES:AN:2015:643., 12. 2. 2015.

105/2010, ES:AN:2015:567., 5. 2. 2015.

359/2010, ES:AN:2015:344., 3. 2. 2015.

565/2010, ES:AN:2015:649., 29. 2. 2015.

567/2010, ES:AN:2015:412., 22. 3. 2015.

727/2010, ES:AN:2015:411., 22. 3. 2015.

317/2011, ES:AN:2015:663., 2. 2. 2015.

370/2011, ES:AN:2015:647., 5. 2. 2015.

434/2011, ES:AN:2015:636., 5. 2. 2015.

456/2011, ES:AN:2015:410., 28. 3. 2015.

498/2011, ES:AN:2015:661., 9. 6. 2015.

567/2011, ES:AN:2013:2552., 24. 5. 2013.

590/2011, ES:AN:2015:484., 10. 2. 2015.

654/2011, ES:AN:2015:641., 5. 2. 2015.

690/2011, ES:AN:2015:342., 3. 2. 2015.

158/2012, ES:AN:2015:2486., 5. 6. 2015.

171/2012, ES:AN:2015:338., 30. 3. 2015.

180/2012, ES:AN:2015:2981., 2. 6. 2015.

183/2012, ES:AN:2014:5208., 29. 12. 2014.

208/2012, ES:AN:2015:2353., 5. 6. 2015.

209/2012, ES:AN:2015:483., 20. 2. 2015.

227/2012, ES:AN:2015:651., 5. 2. 2015.

358/2012, ES:AN:2015:2149., 9. 6. 2015.

360/2012, ES:AN:2015:343., 28. 3. 2015.

411/2012, ES:AN:2015:341., 30. 3. 2015.

489/2012, ES:AN:2015:661., 27. 2. 2015.

493/2012, ES:AN:2015:568., 24. 2. 2015.

498/2012, ES:AN:2015:2487., 11. 6. 2015.

500/2012, ES:AN:2015:1072., 20. 2. 2015.

518/2012, ES:AN:2015:2980., 26. 6. 2015.

23/2013, ES:AN:2015:325., 28. 3. 2015.

24/2013, ES:AN:2015:626., 20. 2. 2015.

205/2013, ES:AN:2015:622., 29. 2. 2015.

276/2013, ES:AN:2015:616., 24. 2. 2015.

277/2013, ES:AN:2015:618., 2. 2. 2015.

278/2013, ES:AN:2015:2338., 1. 6. 2015. 
303/2013, ES:AN:2015:324., 28. 3. 2015.

335/2013, ES:AN:2015:523., 5. 2. 2015.

336/2013, ES:AN:2015:323., 28. 3. 2015.

337/2013, ES:AN:2015:782., 2. 2. 2015.

338/2013, ES:AN:2015:1609., 14. 4. 2015.

364/2013, ES:AN:2015:1228., 20. 3. 2015.

427/2013, ES:AN:2015:621., 29. 2. 2015.

18/2014, ES:AN:2015:2261., 20. 6. 2015.

110/2014, ES:AN:2015:4456., 6.10. 2015.

126/2014, ES:AN:2015:3501., 2. 10. 2015.

17/2014, ES:AN:2015:1838., 26. 4. 2012.

\section{STANDARDS FOR APPLYING THE RIGHT TO BE FORGOTTEN AND THE TEMPORALITY OF FREEDOM OF EXPRESSION IN SPANISH CASE LAW}

\section{Summary}

This paper strives to form a part of the broader debate on the potential threats which the right to be forgotten may pose to freedom of expression on the internet. To that end, it examines the relevant case law of the Spanish courts, which have had the opportunity to develop a substantial practice in applying the right to be forgotten to search engines. The paper begins by bighlighting the main guiding standards of the right to be forgotten, the notion of harm, and the interconnected ideas of the "public" and its interest. This is followed by a discussion on the relationship between these standards and freedom of expression. In this respect, it is posited that the central standard is the "public" and its interest. In Spanish law, the right to receive accurate information has had a dominant impact in providing substance to this standard. Because this is only one aspect of the more general freedom of expression, this right is more likely to favour the processing of data that occurs in a context similar to journalism. By applying it in 'right to be forgotten' cases, a particular temporality of freedom of expression is introduced. Consequently, the processing of personal data that can be justified by providing information in the interest of the collective existence of a political community is more likely to be immune to the right to be forgotten. Nevertheless, it is argued that the right to be forgotten does not pose a threat to freedom of expression. This is particularly so given that its impact is largely neutralised by its restricted field of application, making it effective only in relation to specific internet searches.

Keywords: right to be forgotten, freedom of expression, internet, proportionality, public interest, temporality 